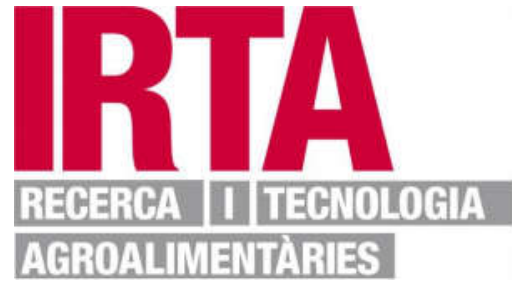

This is the peer reviewed version of the following article: Rios, Liliam, José I. Núñez, Heidy Díaz de Arce, Llilianne Ganges, and Lester J. Pérez. 2018. "Revisiting The Genetic Diversity Of Classical Swine Fever Virus: A Proposal For New Genotyping And Subgenotyping Schemes Of Classification". Transboundary And Emerging Diseases 65 (4): 963-971. Wiley. doi:10.1111/tbed.12909. Wiley, which has been published in final form at https://doi.org/10.1111/tbed.12909. This article may be used for noncommercial purposes in accordance with Wiley Terms and Conditions for Use of SelfArchived Versions 


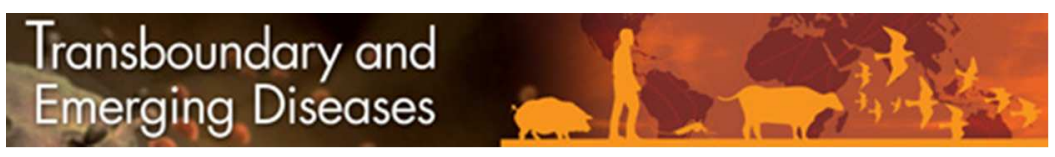

\section{Revisiting the genetic diversity of classical swine fever virus: A proposal for new genotyping and sub-genotyping schemes of classification.}

\begin{tabular}{|r|l|}
\hline Journal: & Transboundary and Emerging Diseases \\
\hline Manuscript ID & TBED-RC-106-18 \\
\hline Manuscript Type: & Rapid Communication \\
\hline Date Submitted by the Author: & $19-$-Feb-2018 \\
\hline Complete List of Authors: & $\begin{array}{l}\text { Rios, Liliam; Dalhousie University Faculty of Medicine, Reiman Cancer } \\
\text { Research Laboratory } \\
\text { Núñez, Jose ; Institut de Recerca i Tecnologia Agroalimentaries, Centre de } \\
\text { Recerca en Sanitat Animal (CReSA, IRTA- UAB) } \\
\text { Diaz de Arce, Heidy; Hospital Italiano de Buenos Aires, Juan D. Perón 4190 } \\
\text { Ganges, Llilianne; OIE Reference Laboratory for Classical Swine Fever } \\
\text { Perez, Lester J; Dalhousie University Faculty of Medicine, DMNB }\end{array}$ \\
\hline Subject Area: & \begin{tabular}{l} 
Virus, Disease control, Veterinary epidemiology \\
\hline
\end{tabular} \\
\hline
\end{tabular}


1 Revisiting the genetic diversity of classical swine fever virus: A proposal for new genotyping and sub-genotyping schemes of classification.

3 Liliam Rios ${ }^{1}$, José I. Núñez ${ }^{2}$, Heidy Díaz de Arce ${ }^{3}$, Llilianne Ganges ${ }^{4}$, Lester J. Pérez ${ }^{5}$

4 Short title: New genetic classification for classical swine fever virus

5

$6 \quad{ }^{1}$ University of New Brunswick, Saint John, New Brunswick, E2L4L5, Canada.

$7 \quad{ }^{2}$ IRTA-CReSA. Centre de Recerca en Sanitat Animal, Barcelona, 08193, Spain.

$8{ }^{3}$ Hospital Italiano de Buenos Aires, Juan D. Perón 4190, C1181ACH Buenos Aires, Argentina

$9{ }^{4}$ OIE Reference Laboratory for Classical Swine Fever, IRTA-CReSA, Barcelona, Spain.

$10{ }^{6}$ Dalhousie University, Dalhousie Medicine New Brunswick, Saint John, New Brunswick, E2L4L5,

11 Canada.

12 *Corresponding author: Tel.:+1 (506)-636-6977 fax:+1 (506)-636-6258

13 E-mail address: lester.perez@dal.ca (Pérez, L.J.)

14 


\section{Abstract}

Classical swine fever (CSF) is a highly contagious febrile viral disease caused by CSF virus

17 (CSFV) and it is considered one of the most important infectious diseases that affect domestic pigs and 18 wild boar. Previous molecular epidemiology studies have revealed that the diversity of CSFV comprises 19 three main genotypes and different subgenotypes defined by using a reliable cut-off to accurately classify 20 CSFV at genotype and subgenotype levels. However, a growing number of CSFV both complete genome 21 and full E2 gene sequences have been submitted to GenBank (more than 500 sequences are currently 22 available, revised on December $\left.1^{\text {st }}, 2017\right)$. Therefore, the aim of the current study was to revisit the 23 taxonomy of CSFV at genotype and subgenotype levels, to unify nomenclature and to provide an update 24 to the classification of CSFV. We propose here a new genotyping scheme with five well defined CSFV25 genotypes (CSFV-Genotype1-5) and 14 subgenotypes (seven for each of the CSFV-Genotype1 and 26 CSFV-Genotype2). The findings showed in the current study are relevant for molecular epidemiology 27 approaches and will help to better understand the genetic diversity and spreading of CSFV at a global 28 scale. The update in the classification of CSFV will allow the scientific community to establish more 29 accurately the links among different outbreaks of the disease. 


\section{$31 \quad$ Introduction}

Classical swine fever (CSF) is a highly contagious febrile viral disease, considered one of the most important infectious diseases that affect domestic pigs and wild boar (Sus scrofa) (Blome et al.,

34 2017). Because of its huge economic impact, the disease is notifiable to the World Organisation of 35 Animal Health (OIE) (Moennig et al., 2013). Even though CSF has been successfully eradicated from 36 some countries including Canada, United States, Australia and New Zealand; it remains to have a severe 37 impact on Asia, Eastern Europe and most of South and Central America as well as the Caribbean (Postel 38 et al., 2017).

CSF is caused by CSF virus (CSFV), a small-enveloped RNA virus of the genus Pestivirus

40 included into the Flaviviridae family. The CSFV genome consists of a single plus-stranded RNA, which

41 contains one large open reading frame (ORF) flanked by two untranslated regions (UTRs). The ORF

42 encodes a polyprotein of approximately 3900 amino acids which is subsequently processed by cellular 43 and viral proteases into mature proteins: four structural proteins (C, Erns, E1 and E2) and 8 non-structural 44 proteins (Npro, P7, NS2, NS3, NS4A, NS4B, NS5A, NS5B)(Meyers and Thiel, 1996).

47 consensus for CSFV's classification system, a recent study assessed the reliability of the phylogenetic 48 markers most commonly used in molecular epidemiology studies of CSFV (Rios et al., 2017). Thus, the 49 phylogenetic marker based on full E2 gene was found to be the best phylogenetic marker, capable of 50 reproducing the same phylogenetic and evolutionary information as the complete viral genome (Rios et 51 al., 2017). In addition, Rios et al. (2017), using the combination of Pairwise Sequence Comparison 52 (PASC), Sequence Demarcation Tool (SDT) analyses and pairwise distance calculation, determined a 53 reliable cut-off to accurately classify CSFV at genotype and subgenotype levels (Rios et al., 2017). Rios 54 et al. (2017) also investigated the evolutionary forces driving the genetic diversity and evolution of 55 CSFV, including the conception of a structural model for E2 protein and other intensive computational 56 analyses. Thus, collecting all these relevant data required a considerable amount of time, consequently, 
57 the dataset of CSFV sequences used in this study included only those available until April 2016. 58 However, a growing number of CSFV both complete genome and full E2 gene sequences have been 59 submitted to GenBank (more than 500 sequences are currently available, revised on December $1^{\text {st }}, 2017$ ), 60 most of them updated after June 2016 when the study published by Rios et al. (2017) was already 61 accomplished. In addition, at the time that the study reported by Rios et al., (2017) was under revision 62 two new subgenotypes (1.5 and 1.6) from CSFV isolates that circulated in Brazil were reported (Silva et 63 al., 2017). This last finding is indicative that the genetic diversity of CSFV could be broader than it was 64 previously reported (Postel et al., 2012, Rios et al., 2017). Hence, the current study was prompted by the 65 increasing number of sequences of CSFV available on GenBank, and follows on the previously published 66 proposals for the classification of CSFV based on $15 \%$ of genetic distance to differ among genotypes and $679 \%$ of genetic distance to consider new subgenotypes (Rios et al., 2017). Therefore, the aim of the current 68 study was to revisit the taxonomy of CSFV at genotype and subgenotype levels, to unify nomenclature 69 and to provide an update to the classification of CSFV. We propose here a new genotyping scheme with 70 five well defined CSFV-genotypes (CSFV-Genotype1-5) and 14 subgenotypes (seven for each of the 71 CSFV-Genotype1 and CSFV-Genotype2). The findings showed in the current study are relevant for 72 molecular epidemiology approaches and will help to better understand the genetic diversity and spreading 73 of CSFV at a global scale.

\section{Material and methods}

\section{Dataset}

76 All available CSFV sequences from both the E2 full gene and the complete genome were downloaded 77 from GenBank on December $1^{\text {st }}, 2017$ (Supplementary material TableS1). The genome region analysed in 78 this study included the full E2 gene as previously proposed by Rios et al. (2017). After removing poor 79 quality and redundant sequences (Supplementary material TableS1, sequence highlighted in gray), a total 80 of 517 sequences of the E2 gene were included in the study (Supplementary material TableS1). 


\section{$81 \quad$ Multiple alignment and Model selection}

82 All sequences were aligned using the MUltiple Sequence Comparison by Log- Expectation (MUSCLE)

83 software freely available at: https://www.ebi.ac.uk/Tools/msa/muscle. The software jModelTest 2.0 was

84 used to estimate the best-fit model using the Akaike and Bayesian information criteria (AIC and BIC)

85 (Darriba et al., 2012). The best-fit model selected was used for phylogenetic analysis and genetic distance

86 calculation.

87 Phylogenetic analysis

88 Phylogenetic analyses were performed following the methodology suggested by Rios et al.

89 (2017), briefly: searches for recombinant sequences and crossover regions were performed to remove the

90 sequences with a possible recombinant event, using Geneconv, RDP, MaxChi, Chimera, BootScan,

91 SiScan, 3Seq and LARD, all implemented in RDP3 Beta 4.1 (Martin and Rybicki, 2000). Phylogenetic

92 relationships of the CSFV strains using the E2 complete gene marker were analyzed using a Maximum

93 Likelihood (ML) approach. The sequences JX428945/NC_018713 belonging to the Pestivirus Aydin were

94 used as outgroup.

95 Calculation of pairwise nucleotide p-distances and PAirwise Sequence Comparison (PASC) analysis.

96 Pairwise nucleotide p-distances were calculated using MEGA7 (Kumar et al., 2016). Different matrix of

97 nucleotide divergence between groups were generated using an alpha-value $=0.66$ and 1000 bootstrap

98 replicates to estimate variance. To confirm the reliability of the cut-off previously defined by Rios et al.

99 (2017) for the different lineages of CSFV, a PASC analysis was performed. Thus, all 517 unique CSFV

100 sequences for E2 full gene were submitted to the web tool DIVEIN (Deng et al., 2010) and a histogram

101 based on computing the divergence/diversity among and within CSFV lineages was accomplished.

\section{Results and Discussion}

103 The PASC analyses, based on the E2 gene from the 517 E2 full gene sequences, displayed a 104 multimodal curve (Fig. 1A), similar to the results obtained by Rios et al. (2017). Threshold values of $91 \%$ 105 and $86 \%$ of identity allow to separate all the subgenotypes and genotypes of CSFV, respectively (Fig. 106 1A). Thus, the cut-off values were consistent with those previously obtained by Rios et al. (2017). It's 
107 important to denote that the cut-off values were not changed by the effect of the number of sequences 108 employed. For other viral agents such as porcine circovirus type 2 (PCV2), when the taxonomy was 109 revisited due to conflicting results obtained by different research groups (Franzo et al., 2015), it was 110 evidenced that the increase in the number of sequences analysed yielded incompatible cut-off values 111 (Franzo et al., 2015) compared to those previously established (Grau-Roma et al., 2008). Thus, the fact 112 that the cut-off values to define CSFV genotypes and subgenotypes were not altered despite the 5-fold 113 increase of the total of sequences analysed, ensures the accurate classification for this viral agent.

114 ML tree, based on the complete E2 gene from 517 CSFV sequences, identified five main lineages 115 (CSFV genotypes 1-5) and different sublineages (Fig. 1B). In addition, the genetic divergence among the 116 different proposed CSFV-Genotypes ranged between 15.6\%-19.1\% (Fig. 1C). Thus, beside the 117 historically recognized CSFV-Genotypes 1-3 (Postel et al., 2012), two new genotypes are proposed in this 118 study. One of the new proposed genotypes was formed by the British CSFV strain "Congenital Tremor" 119 isolated in 1964 (sequence ID:JQ411575) (Vilcek et al., 1996). This strain was found to be one of the 120 most distinct strains in a phylogenetic study performed in 1996 (Vilcek et al., 1996), and it was later 121 misplaced as outgroup, in molecular epidemiology studies of CSFV (Postel et al., 2012, Postel et al., 122 2017). In the current study, CSFV strain "Congenital Tremor" showed a genetic divergence, compared to 123 the remaining CSFV-genotypes, between $15.7 \%-17.4 \%$ (Fig. 1C). It is also important to denote that in 124 phylogenetic analysis at species level, where rooted trees are analyzed, those sequences from species 125 closer to the specie in study must be used as outgroup (Perez et al., 2011, Martinez et al., 2012, Barrera et 126 al., 2017, Holland et al., 2003). Since CSFV strain "Congenital Tremor" (sequence ID: JQ411575) 127 showed less that $20 \%$ of genetic divergence when compared to the remaining CSFV genotypes, this strain 128 is a CSFV member and therefore, its use as outgroup is not appropriate when phylogenetic analyses are 129 conducted at species level. However, the branch formed by this strain is divergent enough from CSFV130 genotype 2 to be considered a new genotype. The fact that the number of full sequences of CSFV E2 gene 131 has increased considerably in the GenBank Database could have helped resolve this new topology 
132 showing CSFV strain "Congenital Tremor" as a divergent lineage. Therefore, we propose this lineage to 133 be designated as a new CSFV-genotype (CSFV-genotype 4) (Fig. 1B and C).

In addition to the CSFV strain "Congenital Tremor", the CSFV strains JJ9811 and YI9908

135 isolated from Korea during 1998 and 1999, respectively, formed a statistically supported independent 136 lineage (Fig.1B). This lineage showed a genetic divergence compared to the remaining CSFV-genotypes 137 that ranged between 15.6\%-19.1\% (Fig. 1C). The CSFV strains JJ9811 and YI9908 have been previously 138 classified as genotype 3, subgenotype 3.2 (Lim et al., 2016). However, this previous classification was 139 based on the phylogenetic analysis using the segment of E2 comprising $190 \mathrm{nt}$ (E2-190 marker) (Lowings 140 et al., 1996). In a previous report, it was shown that the phylogenetic marker E2-190 (Lowings et al., 141 1996) was associated with loss of phylogenetic information, besides, this marker was unable to reproduce 142 the same topologies as the complete genome of CSFV or the E2-complete gene marker (Rios et al., 2017). 143 A notable example showing the misclassification leaded by the use of the E2-190 marker is the case of the 144 Cuban CSFV isolates, which were historically classified as subgenotype 1.2 (Diaz de Arce et al., 1999, de 145 Arce et al., 2005, Perez et al., 2012). However, these isolates were re-classified as subgenotype 1.4 when 146 the phylogenetic analysis was accomplished using the E2-complete gene marker showed a genetic 147 segregation between $9.8-15.8 \%$ to sequences of subgenotype 1.2 (Postel et al., 2013). Thus, the use of 148 the marker E2-190 (Lowings et al., 1996), could have lead to a misclassification of the CSFV strains 149 JJ9811 and YI9908 into the subgenotype 3.2 (Lim et al., 2016). It is also relevant to consider that the 150 lineage formed by the CSFV strains JJ9811 and YI9908 showed a genetic divergence of 16.6\% with the 151 CSFV strains belonging to the genotype 3 (Fig. 1B and C). Thus, both analyses (the topology and the 152 genetic divergence of the lineage formed by the CSFV strains JJ9811 and YI9908) support the divergence 153 of this new lineage and we propose to designate it as a new CSFV-genotype (CSFV-genotype 5) (Fig. 1 154 and Supplementary Material Fig.S1).

155 At intra-genotype level, a new scheme of the genetic diversity was also revealed (Fig. 2, Fig. 3 156 and Table 1). In the case of CSFV-genotype 1, seven subgenotypes were found, consisting of the four 157 (1.1-1.4) previously recognized (Postel et al., 2013, Rios et al., 2017), the two new subgenotypes (1.5-1.6) 
158 recently described circulating in Brazil (Silva et al., 2017), and a new subgenotype reported for the first 159 time in the current study designated as CSFV- subgenotype 1.7 (Fig.2 and Table 1). The new subgenotype 1601.7 was strongly supported by bootstrap values and the genetic divergence showed in comparison with the 161 remaining subgenotypes (Fig.2 and Table 1). Thus, the CSFV subgenotype 1.7 showed a genetic 162 divergence ranged from $9.2 \%$ to $13.1 \%$ (Table 1 ).

163 The new 1.7 subgenotype comprised 20 sequences (KX586754-KX586772, and KX586774), all 164 from viral strains circulating in Ecuador during 2012 to 2015. Moreover, another sequence included in 165 this study (KX586773) of a strain circulating in Ecuador in March of 2000 clustered together with the 166 CSFV subgenotype 1.1. Hence, a switch from the subgenotype 1.1 to subgenotype 1.7 occurred in 167 Ecuador during 2000 to 2012, caused by an event not yet reported.

168 Even though a phylodynamic study focused on Ecuadorian CSFV strains has been recently 169 reported (Garrido Haro et al., 2018), no epidemiological information about this new cluster was 170 discussed. Likewise, it's important to highlight that the phylodynamic analysis in this study was very 171 limited, since only the B/C domain of the E2 gene (190 nt) was considered. Although Garrido-Haro et al. 172 (2018) sequenced the complete gene E2 from Ecuadorian strains, these authors included in their analysis 173 Peruvian strains (Genbank Acc. No. HM070972, HM070975, HM070976, HM070977, HM070982 and 174 HM070988 (See Figure 1 in Garrido-Haro et al. (2018)), which are partial E2 sequences, framing the B/C 175 domain region. Therefore, all the inferences performed in the different analyses in Garrido-Haro et al. 176 (2018) (time for the most recent common ancestor (tMRCA), Bayesian Skyline Plot (BSP) and 177 evolutionary rates) were restricted to the $\mathrm{B} / \mathrm{C}$ domain region, which has been recently described to bias 178 the results for phylogenetic and phylodynamic approaches in CSFV (Rios et al., 2017). Therefore, further 179 studies will be required to get a better understanding about the events supporting the switch of the 180 subgenotype 1.1 to 1.7 in Ecuador. We also remark that the new cluster containing the CSFV-strains 181 circulating in Ecuador was previously classified as subgenotype 1.6 together with strains that circulated in 182 Brazil and Peru during the years 2008 and 2009 (Garrido Haro et al., 2018). However, analysing in detail 183 the results reported by Garrido-Haro et al. (2018), it can be noted that the Ecuadorian strains formed a 
184 segregated cluster from the Brazilian and Peruvian strains. In addition, these authors didn't perform a 185 genetic divergence analysis leading to a misclassification of this new group of strains circulating in 186 Ecuador.

The results obtained in the current study from the genetic divergence evaluation among all the 188 statistically supported lineages (Fig. 2), showed that no additional subgenotypes within the CSFV189 genotype 1 were supported (Supplementary material TableS2).

190 Regarding CSFV-genotype 2, besides the three previously reported subgenotypes (Postel et al., 191 2012, Rios et al., 2017), another four subgenotypes were identified (Fig. 3, Table 1) from the 19 192 sublineages assessed (Supplementary material TableS3). The lineage formed by sequences of CSFV 193 strains that circulated in India during 2012-2013 formed a statistically supported cluster (Fig. 3 and 194 Supplementary material TableS1). These sequences showed a genetic divergence of $11.9 \%$ with the 195 subgenotype 2.1, where the strains were previously located (Ahuja et al., 2015), and a genetic divergence 196 compared to the remaining subgenotypes into CSFV-genotype 2 that ranged between $9.1 \%$ and $13.8 \%$ 197 (Table 1). Hence, we propose this lineage to be defined as subgenotype 2.4 (Fig. 3). Likewise, the lineage 198 consisting of CSFV strains that circulated in China during 2008 to 2013 and in Viet Nam in 2014 (Fig. 3 199 and Supplementary material TableS1) formed a statistically supported cluster (Fig. 3 and Supplementary 200 material TableS1) and showed a genetic divergence of $9.1 \%$ with the subgenotype 2.1, where the strains 201 were previously located, thus we propose to define this lineage as CSFV subgenotype 2.5 (Fig.3). It is 202 important to highlight that both CSFV subgenotypes 2.4 and 2.5 were previously defined as subgenotypes 203 2.1d and 2.1c, respectively (Gong et al., 2016). Gong et al. (2016) also proposed another eight 204 subgenotypes for a total of ten new subgenotypes all diversified from the subgenotype 2.1 (Gong et al., 205 2016). However, a detailed analysis accomplished in Rios et al. (2017) showed that neither the genetic 206 divergence showed by the lineages nor the statistical values in the topology resolved were enough to 207 support the classification of these lineages as new subgenotypes (Rios et al., 2017).

208 In the current study, a supported diversification from the branch that originated the subgenotype 2092.1 yielded two new lineages (subgenotype 2.4 and subgenotype 2.5) (Fig. 3). The effect of the number of 
210 taxa on the support of the nodes in the phylogenetic tree has been previously reported as key element to

211 be considered in the phylogenetic tree reconstruction (Simion et al., 2017, Philippe et al., 2011). In

212 addition, it is well known that including more taxa allows a better detection of multiple substitutions,

213 decreasing the amount of non-phylogenetic signal while preserving phylogenetic signal, which can be

214 translated in a better resolution of the topology (Philippe et al., 2011). Therefore, the fact that the number

215 of sequences used in the current study has been increased approximately in 3-fold in comparison with the

216 sequences used in Gong et al. (2016) (517 sequences vs 160 sequences used in Gong et al. (2016)) clearly

217 improved the support of the node in the topologies obtained. Likewise, it has been previously

218 demonstrated, taking into account the postulates of the neutral theory of evolution, that genetic diversity

219 increases with a larger effective population size (Hague and Routman, 2016). Hence, the taxa number

220 increase could have been determinant in obtaining the genetic distance values for the subgenotypes 2.4

221 and 2.5 (Table 1 and supplementary material TableS3). Despite these novel results, it is also relevant to

222 denote that, non-additional subgenotypes were found from the diversification of the subgenotype 2.1

223 (Figure 3 and supplementary material TableS3). Thus, in this regard, the present work reinforces the

224 results previously described by Rios et al. (2017) which evidenced that subgenotypes 2.1 a,b,g,h,i and j

225 defined by Gong et al. (2016) are not distinct enough to be regarded as new subgenotypes.

226 In addition to the two new subgenotypes (2.4 and 2.5) which emerged from the same ancestor

227 than subgenotype 2.1, another two subgenotypes (2.6 and 2.7) were defined into the CSFV genotype 2

228 (Fig. 3 and Table 1). These two proposed subgenotypes, emerged from the same ancestor than

229 subgenotype 2.2 (Fig. 3). The new proposed subgenotype 2.6 consisted of strains circulating in Viet Nam

230 in 2014 (Supplementary information TableS1) with an ancestral CSFV strain that circulated in Italy in

2311998 (Supplementary information TableS1). A recent report by Hung et al. (2017) described the same

232 topological reconstruction for these Vietnamese strains emerging from the ancestral CSFV-strain

233 CSF0573-Parma circulating in Italy in 1998 (Hung, 2017). However, since Hung et al. (2017) only

234 employed a total of 29 sequences of CSFV, it was not possible to obtain a genetic divergence of this

235 cluster with an accurate resolution compared to subgenotype 2.2 (Hung, 2017). In the current study, the 
236 independent segregation of this lineage (defined as 2.6) was statistically supported by a 100\% of bootstrap 237 value. In addition, the new proposed subgenotype 2.6 showed a genetic distance of $13.0 \%$ compared with 238 subgenotype 2.2 (Table 1) and the genetic divergence compared with the remaining subgenotypes was 239 ranged between $9.3 \%$ and $13.0 \%$. Therefore, based on all the results obtained, we consider this lineage as 240 a new subgenotype designated as 2.6 (Fig.3 and Table 1).

241 Surprisingly, the strain Bergen isolated in Netherlands in 1977 formed an independent lineage, 242 statistically supported with $85 \%$ of bootstrap value (Fig. 3) and showed a genetic divergence of $10.8 \%$ 243 compared to subgenotype 2.2 (Table 1), where it was previously included (Postel et al., 2012). Relevant 244 aspects need to be clarified regarding this result. First, the lineage proposed as the new subgenotype 2.7 245 was composed by two non-identical sequences from the CSFV Bergen strain. This strain has four 246 sequences on Genbank database: one sequence for the complete E2 gene (JQ411587), another sequence 247 for the complete genome (KJ619377) and two sequences for the NS5B region (U30720 and AF182909). 248 However, both E2 sequences for this viral strain (JQ411587 and the E2 sequence extracted from the 249 complete genome (KJ619377)) are not identical, therefore, they were analyzed independently. Second, in 250 a previous report, it was highlighted that CSFV-strain Netherlands/JQ411587 "Bergen" (CSF0906) 251 partially displayed a higher genetic similarity to some genotype 2.1 isolates than to different 2.2 isolates, 252 disturbing the segregation of 2.1 and 2.2 isolates (Postel et al., 2012). However, since Postel et al. (2012) 253 only used 33 CSFV sequences, they also faced the trouble of acquiring both an accurate resolution and a 254 proper genetic divergence of this new cluster compared the subgenotype 2.2.

255 On the other hand, for the remining genotypes (CSFV-genotype 3, CSFV-genotype 4 and CSFV256 genotype 5) a diversification in additional subgenotypes was not detected (Supplementary material Fig. 257 S2, Table S4 and S5).

258 In the current study, a new classification scheme for CSFV is proposed. The increased number of 259 CSFV sequences available on GenBank database, especially of the full E2 gene, facilitated obtaining a 260 better resolution for the topology of CSFV-tree. In addition, the establishment of a reliable cut-off value 261 by Rios et al. (2017) made possible to accurately define genotypes and subgenotypes for CSFV. Similar 
262 approaches have been accomplished for other viral agents. Thus, the growing number of sequences for 263 infectious bursal disease virus (IBDV) and the use of phylogenetic methodologies have enabled a new 264 classification of this viral agent into seven genogroups, updating the previous classification which only 265 recognized three groups (Michel and Jackwood, 2017). Likewise, for porcine circovirus type 2 (PCV2), a 266 new genotype has been added to the previous taxonomic classification, after the analysis of approximately 2673300 new sequences of the complete genome of this virus (Franzo et al., 2016), which were submitted to 268 GenBank database after the first taxonomical classification for PCV2 had been accomplished (Grau269 Roma et al., 2008). The current study also highlights the importance of submitting non-redundant 270 sequences for CSFV. Although a new classification scheme is provided here, it is relevant to denote that 271 some phylogenetic clades have better representation of viral isolates than others. Thus, we encourage the 272 different research groups to increase their molecular epidemiology studies regarding CSFV, which can 273 stimulate the acquisition of new representative CSFV sequences. Finally, the results presented here will 274 facilitate future analyses focused on elucidating evolutionary relationships among different CSFV 275 isolates. The update in the classification of CSFV will allow the scientific community to establish more 276 accurately the links among different outbreaks of the disease.

277

278 Conflict of interest

279 The authors declare no conflict of interest.

280 Author contribution

281 L.J.P. designed the research; L.J.P. and L.R performed the phylogenetic analysis; L.J.P., L.R., H.D-A., 282 L.G., and J.I.N. analyzed and interpreted the data; L.J.P. and L.R. wrote the paper; L.G., J.I.N. and H.D283 A edit the paper and provided intellectual inputs. All the authors read and approved the final version of 284 the manuscript.

\section{Guarantor Statement}

286 Dr. Lester J. Pérez, is the guarantor of this work, had full access to all the data, and takes full 287 responsibility for the integrity of data and the accuracy of data analysis. 


\section{References}

Ahuja, A., U. Bhattacharjee, A. K. Chakraborty, A. Karam, S. Ghatak, K. Puro, S. Das, I. Shakuntala, N. Srivastava, S. V. Ngachan and A. Sen, 2015: Complete genome sequence of classical Swine Fever virus subgenogroup 2.1 from assam, India. Genome announcements, 3.

Barrera, M., A. Garrido-Haro, M. S. Vaca, D. Granda, A. Acosta-Batallas and L. J. Pérez, 2017: Tracking the Origin and Deciphering the Phylogenetic Relationship of Porcine Epidemic Diarrhea Virus in Ecuador. BioMed research international, 2017, 7.

Blome, S., C. Staubach, J. Henke, J. Carlson and M. Beer, 2017: Classical Swine Fever-An Updated Review. Viruses, 9.

Darriba, D., G. L. Taboada, R. Doallo and D. Posada, 2012: jModelTest 2: more models, new heuristics and parallel computing. Nature methods, 9, 772.

de Arce, H. D., L. Ganges, M. Barrera, D. Naranjo, F. Sobrino, M. T. Frias and J. I. Nunez, 2005: Origin and evolution of viruses causing classical swine fever in Cuba. Virus research, 112, 123-131.

Deng, W., B. S. Maust, D. C. Nickle, G. H. Learn, Y. Liu, L. Heath, S. L. Kosakovsky Pond and J. I. Mullins, 2010: DIVEIN: a web server to analyze phylogenies, sequence divergence, diversity, and informative sites. Biotechniques, 48, 405-408.

Diaz de Arce, H., J. I. Nunez, L. Ganges, M. Barreras, M. Teresa Frias and F. Sobrino, 1999: Molecular epidemiology of classical swine fever in Cuba. Virus research, 64, 61-67.

Franzo, G., M. Cortey, A. Olvera, D. Novosel, A. M. Castro, P. Biagini, J. Segales and M. Drigo, 2015: Revisiting the taxonomical classification of Porcine Circovirus type 2 (PCV2): still a real challenge. Virology journal, 12, 131.

Franzo, G., M. Cortey, J. Segales, J. Hughes and M. Drigo, 2016: Phylodynamic analysis of porcine circovirus type 2 reveals global waves of emerging genotypes and the circulation of recombinant forms. Molecular phylogenetics and evolution, 100, 269-280.

Garrido Haro, A. D., M. Barrera Valle, A. Acosta and J. F. F, 2018: Phylodynamics of classical swine fever virus with emphasis on Ecuadorian strains. Transboundary and emerging diseases.

Gong, W., J. Wu, Z. Lu, L. Zhang, S. Qin, F. Chen, Z. Peng, Q. Wang, L. Ma, A. Bai, H. Guo, J. Shi and C. Tu, 2016: Genetic diversity of subgenotype 2.1 isolates of classical swine fever virus. Infection, genetics and evolution : journal of molecular epidemiology and evolutionary genetics in infectious diseases, 41, 218-226.

Grau-Roma, L., E. Crisci, M. Sibila, S. Lopez-Soria, M. Nofrarias, M. Cortey, L. Fraile, A. Olvera and J. Segales, 2008: A proposal on porcine circovirus type 2 (PCV2) genotype definition and their relation with postweaning multisystemic wasting syndrome (PMWS) occurrence. Veterinary microbiology, 128, 23-35.

Hague, M. T. and E. J. Routman, 2016: Does population size affect genetic diversity? A test with sympatric lizard species. Heredity, 116, 92-98.

Holland, B. R., D. Penny and M. D. Hendy, 2003: Outgroup misplacement and phylogenetic inaccuracy under a molecular clock--a simulation study. Systematic biology, 52, 229-238.

Hung, N. P., Lan, N.T., Nga, B.T.T., Truong, T., Phan, L.V., 2017: Genetic Characterization of E2 gene of classical swine fever virus circulating in Nam Dinh and Hai Duong Provinces. Vietnam Journal of Agricultural Science, 15, 8.

Kumar, S., G. Stecher and K. Tamura, 2016: MEGA7: Molecular Evolutionary Genetics Analysis Version 7.0 for Bigger Datasets. Mol Biol Evol, 33, 1870-1874.

Lim, S. I., S. H. Han, H. Hyun, J. A. Lim, J. Y. Song, I. S. Cho and D. J. An, 2016: Complete Genome Sequence Analysis of Acute and Mild Strains of Classical Swine Fever Virus Subgenotype 3.2. Genome announcements, 4.

Lowings, P., G. Ibata, J. Needham and D. Paton, 1996: Classical swine fever virus diversity and evolution. The Journal of general virology, 77 ( Pt 6), 1311-1321. 
338

339

340

341

342

343

344

345

346

347

348

349

350

351

352

353

354

355

356

357

358

359

360

361

362

363

364

365

366

367

368

369

370

371

372

373

374

375

376

377

378

379

380

381

382

383

384

385

Martin, D. and E. Rybicki, 2000: RDP: detection of recombination amongst aligned sequences. Bioinformatics, 16, 562-563.

Martinez, N., P. E. Brandao, S. P. de Souza, M. Barrera, N. Santana, H. D. de Arce and L. J. Perez, 2012: Molecular and phylogenetic analysis of bovine coronavirus based on the spike glycoprotein gene. Infection, genetics and evolution : journal of molecular epidemiology and evolutionary genetics in infectious diseases, 12, 1870-1878.

Meyers, G. and H. J. Thiel, 1996: Molecular characterization of pestiviruses. Advances in virus research, 47, 53-118.

Michel, L. O. and D. J. Jackwood, 2017: Classification of infectious bursal disease virus into genogroups. Archives of virology, 162, 3661-3670.

Moennig, V., P. Becher and M. Beer, 2013: Classical swine fever. Developments in biologicals, 135, 167-174.

Perez, L. J., H. D. de Arce, M. Cortey, P. Dominguez, M. I. Percedo, C. L. Perera, J. Tarradas, M. T. Frias, J. Segales, L. Ganges and J. I. Nunez, 2011: Phylogenetic networks to study the origin and evolution of porcine circovirus type 2 (PCV2) in Cuba. Veterinary microbiology, 151, 245-254.

Perez, L. J., H. Diaz de Arce, C. L. Perera, R. Rosell, M. T. Frias, M. I. Percedo, J. Tarradas, P. Dominguez, J. I. Nunez and L. Ganges, 2012: Positive selection pressure on the B/C domains of the E2-gene of classical swine fever virus in endemic areas under $\mathrm{C}$-strain vaccination. Infection, genetics and evolution : journal of molecular epidemiology and evolutionary genetics in infectious diseases, 12, 1405-1412.

Philippe, H., H. Brinkmann, D. V. Lavrov, D. T. Littlewood, M. Manuel, G. Worheide and D. Baurain, 2011: Resolving difficult phylogenetic questions: why more sequences are not enough. PLoS biology, 9, e1000602.

Postel, A., S. Austermann-Busch, A. Petrov, V. Moennig and P. Becher, 2017: Epidemiology, diagnosis and control of classical swine fever: Recent developments and future challenges. Transboundary and emerging diseases.

Postel, A., S. Schmeiser, J. Bernau, A. Meindl-Boehmer, G. Pridotkas, Z. Dirbakova, M. Mojzis and P. Becher, 2012: Improved strategy for phylogenetic analysis of classical swine fever virus based on full-length $\mathrm{E} 2$ encoding sequences. Veterinary research, 43,50 .

Postel, A., S. Schmeiser, C. L. Perera, L. J. Rodriguez, M. T. Frias-Lepoureau and P. Becher, 2013: Classical swine fever virus isolates from Cuba form a new subgenotype 1.4. Veterinary microbiology, 161, 334-338.

Rios, L., L. Coronado, D. Naranjo-Feliciano, O. Martinez-Perez, C. L. Perera, L. HernandezAlvarez, H. Diaz de Arce, J. I. Nunez, L. Ganges and L. J. Perez, 2017: Deciphering the emergence, genetic diversity and evolution of classical swine fever virus. Scientific reports, 7, 17887.

Silva, M. N., D. M. Silva, A. S. Leite, A. L. Gomes, A. C. Freitas, J. W. Pinheiro-Junior, R. S. Castro and A. L. Jesus, 2017: Identification and genetic characterization of classical swine fever virus isolates in Brazil: a new subgenotype. Archives of virology, 162, 817-822.

Simion, P., H. Philippe, D. Baurain, M. Jager, D. J. Richter, A. Di Franco, B. Roure, N. Satoh, E. Queinnec, A. Ereskovsky, P. Lapebie, E. Corre, F. Delsuc, N. King, G. Worheide and M. Manuel, 2017: A Large and Consistent Phylogenomic Dataset Supports Sponges as the Sister Group to All Other Animals. Current biology : CB, 27, 958-967.

Vilcek, S., T. Stadejek, A. Ballagi-Pordany, J. P. Lowings, D. J. Paton and S. Belak, 1996: Genetic variability of classical swine fever virus. Virus research, 43, 137-147. 
Table 1. Genetic distances based on full-length E2 gene sequences of CSFV for different subgenotypes. Values above the diagonal represent the standard error, values below the diagonal represent the p-distance values obtained using MEGA7 and 1000 bootstrap replicates

\begin{tabular}{|r|rrrrrrrrrrrrrr|r|}
\hline Subgenotype & $\mathbf{1 . 1}$ & $\mathbf{1 . 2}$ & $\mathbf{1 . 3}$ & $\mathbf{1 . 4}$ & $\mathbf{1 . 5}$ & $\mathbf{1 . 6}$ & $\mathbf{1 . 7}$ & $\mathbf{2 . 1}$ & $\mathbf{2 . 2}$ & $\mathbf{2 . 3}$ & $\mathbf{2 . 4}$ & $\mathbf{2 . 5}$ & $\mathbf{2 . 6}$ & $\mathbf{2 . 7}$ \\
\hline $\mathbf{1 . 1}$ & & 0.007 & 0.008 & 0.009 & 0.002 & 0.001 & 0.002 & & & & & & \\
$\mathbf{1 . 2}$ & 0.096 & & 0.006 & 0.004 & 0.008 & 0.009 & 0.005 & & & & & \\
$\mathbf{1 . 3}$ & 0.104 & 0.102 & & 0.009 & 0.001 & 0.001 & 0.009 & & & & & & \\
$\mathbf{1 . 4}$ & 0.116 & 0.107 & 0.120 & & 0.011 & 0.001 & 0.001 & & & & & & & \\
$\mathbf{1 . 5}$ & 0.096 & 0.131 & 0.138 & 0.134 & & 0.007 & 0.009 & & & & & & & \\
$\mathbf{1 . 6}$ & 0.095 & 0.118 & 0.137 & 0.134 & 0.098 & & 0.009 & & & & & & & \\
$\mathbf{1 . 7}$ & 0.096 & 0.104 & 0.128 & 0.131 & 0.108 & 0.106 & & & & & & & & \\
$\mathbf{2 . 1}$ & & & & & & & & & 0.008 & 0.012 & 0.011 & 0.002 & 0.001 & 0.008 \\
$\mathbf{2 . 2}$ & & & & & & & & 0.134 & & 0.008 & 0.012 & 0.012 & 0.012 & 0.012 \\
$\mathbf{2 . 3}$ & & & & & & & & 0.138 & 0.130 & & 0.012 & 0.013 & 0.012 & 0.012 \\
$\mathbf{2 . 4}$ & & & & & & & & & 0.119 & 0.135 & 0.136 & & 0.012 & 0.012 & 0.001 \\
$\mathbf{2 . 5}$ & & & & & & & & 0.097 & 0.130 & 0.138 & 0.113 & & 0.004 & 0.001 \\
$\mathbf{2 . 6}$ & & & & & & & & 0.099 & 0.130 & 0.130 & 0.107 & 0.097 & & 0.001 \\
$\mathbf{2 . 7}$ & & & & & & & & 0.147 & 0.108 & 0.131 & 0.139 & 0.133 & 0.146 \\
\hline
\end{tabular}




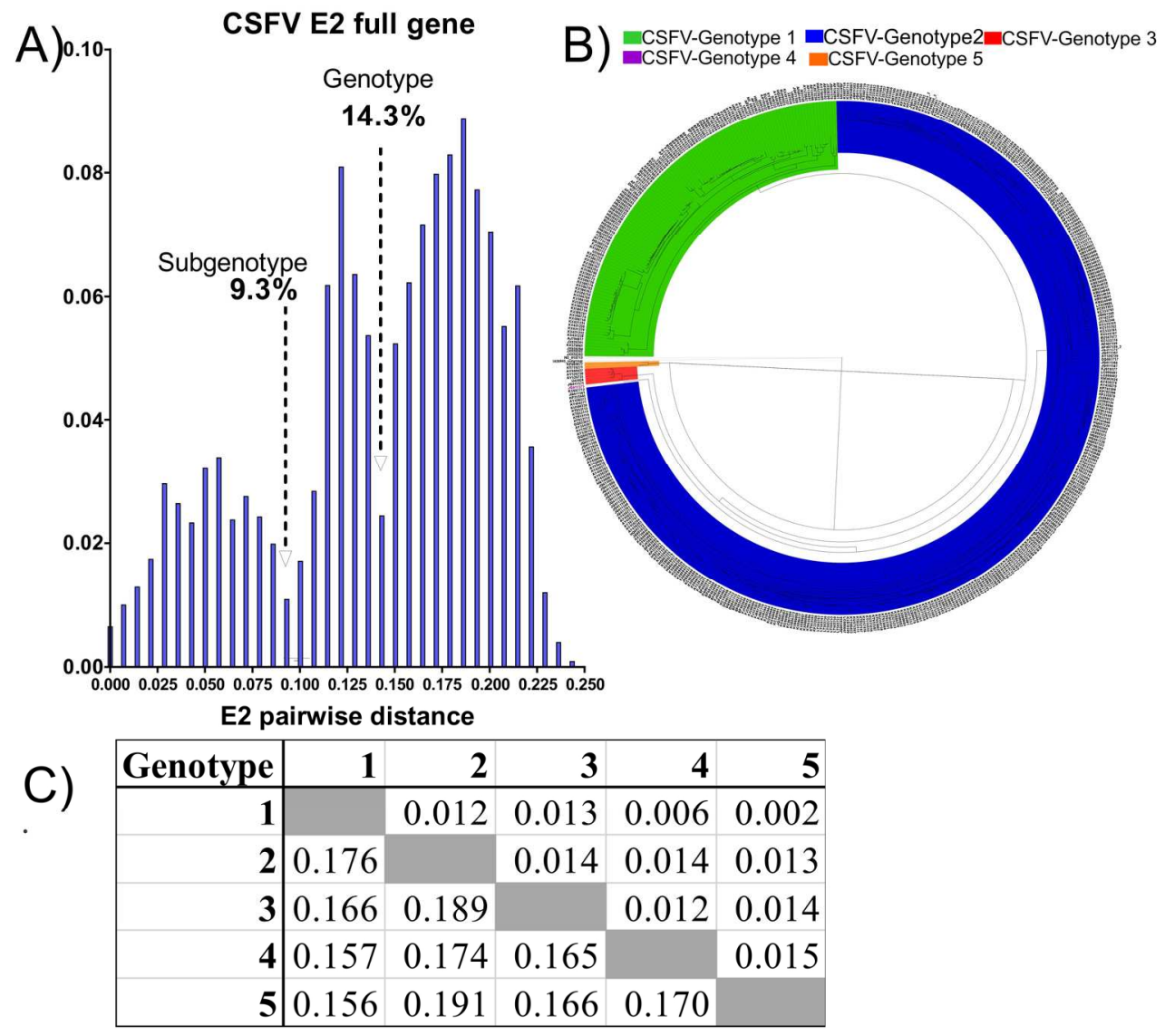

Fig. 1. Representation of frequency distribution of pairwise distance, the phylogenetic tree and genetic distance for all the five-main lineage of CSFV. A) PASC results: the cut-off values genotype (14.3\%) and subgenotype (9.3\%) of genetic divergence were denoted. B) All no-redundant genomes were analysed using ML-method, the GenBank IDs for all the sequence is shown, the main lineages proposed as CSFV-genotypes are denoted (CSFV-genotype 1: green, CSFV-genotype 2: blue, CSFV-genotype 3: red, CSFV-genotype 4:

purple, and CSFV-genotype 5: orange (this tree has been used with representation purposes only, an additional tree showing the significance value for the nodes is shown in Supplementary material Fig.S1.C) Pdistance between CSFV-genotypes, 1, 2, 3, 4 and 5: Indicates the CSFV genotypes 1, 2, 3, 4 and 5, respectively. Values above the diagonal represent the standard error, values below the diagonal represent the p-distance values obtained using MEGA7 and 1000 bootstrap replicates.

$177 \times 155 \mathrm{~mm}(300 \times 300 \mathrm{DPI})$ 
Fig. 2. Phylogenetic tree for CSFV genotype 1. All non-redundant genomes were analysed using ML-method, the GenBank IDs for all the sequences are shown. All the lineages assessed within the CSFV genotype 1 (green) are denoted with black circles, the main sublineages proposed as CSFV subgenotypes within CSFV genotype 1 are denoted. All the remaining CSFV genotypes were collapsed: CSFV-genotype 2: blue, CSFVgenotype 3: red, CSFV-genotype 4: purple, and CSFV-genotype 5: orange. Numbers along the branches refer to the percentages of confidence and minor branch values were hidden.

$$
139 \times 153 \mathrm{~mm}(300 \times 300 \text { DPI })
$$


Fig. 3. Phylogenetic tree for CSFV genotype 2. All non-redundant genomes were analysed using ML-method, the GenBank IDs for all the sequences are shown. All the lineages assessed within the CSFV genotype 2 (blue) are denoted with black circles, the main sublineages proposed as CSFV subgenotypes within CSFV genotype 2 are denoted. All the remaining CSFV genotypes were collapsed: CSFV-genotype 1: green, CSFVgenotype 3: red, CSFV-genotype 4: purple, and CSFV-genotype 5: orange. Numbers along the branches refer to the percentages of confidence and minor branch values were hidden

$$
203 \times 270 \mathrm{~mm}(300 \times 300 \mathrm{DPI})
$$




\begin{tabular}{|l|l|l|}
\hline GenBank ID & Country & \multicolumn{1}{l|}{ Collection Date } \\
\hline AF352565 & Taiwan & Not available \\
\hline AB897785 & Japan & 2012 \\
\hline D49533 & Japan & Not available \\
\hline D49532 & Japan & Not available \\
\hline AF407339 & China & Not available \\
\hline LT593749 & Not available & Not available \\
\hline LT593750 & Not available & Not available \\
\hline LT593751 & Not available & Not available \\
\hline LT593757 & Not available & Not available \\
\hline LT593758 & Not available & Not available \\
\hline LT593748 & Not available & Not available \\
\hline LT593754 & Not available & Not available \\
\hline LT593760 & Not available & Not available \\
\hline KY849593 & Serbia & 2005 \\
\hline KY849594 & Serbia & 2006 \\
\hline LT593752 & Not available & Not available \\
\hline LT593753 & Not available & Not available \\
\hline LT593755 & Not available & Not available \\
\hline LT593756 & Not available & Not available \\
\hline LT593759 & Not available & Not available \\
\hline LT593761 & Not available & Not available \\
\hline LT593762 & Not available & Not available \\
\hline JQ595295 & Belgium & $1993-1994$ \\
\hline AY072924 & Denmark & Not available \\
\hline LC016722 & Thailand & 1993 \\
\hline JQ411563 & Germany & 1992 \\
\hline JQ411564 & Germany & 1994 \\
\hline JQ411565 & Austria & 1994 \\
\hline JQ411568 & Poland & 1995 \\
\hline JQ411572 & Czech Republic & 1996 \\
\hline JQ411574 & Germany & 1997 \\
\hline JQ411576 & Germany & 1995 \\
\hline JQ411577 & Germany & 1997 \\
\hline JQ411580 & Germany & 1998 \\
\hline JQ411581 & Germany & 1998 \\
\hline JQ411583 & Slovakia & 2000 \\
\hline JQ411584 & Germany & 2000 \\
\hline JQ411585 & Spain & 2001 \\
\hline JQ411586 & Croatia & 2006 \\
\hline JQ411559 & Germany & 1984 \\
\hline JQ411560 & 1989 \\
\hline JQ411561 & 1990 \\
\hline JQ411562 & \\
\hline
\end{tabular}




\begin{tabular}{|l|l|l|}
\hline JQ411566 & Germany & 1997 \\
\hline JQ411567 & Netherlands & 1997 \\
\hline JQ411569 & Poland & 1995 \\
\hline JQ411570 & Malaysia & 1986 \\
\hline JQ411571 & Japan & 1974 \\
\hline JQ411573 & Czech Republic & 1994 \\
\hline JQ411575 & United Kingdom & 1964 \\
\hline JQ411578 & Germany & 1982 \\
\hline JQ411579 & Italy & 1998 \\
\hline JQ411582 & United Kingdom & 2000 \\
\hline JQ411587 & Netherlands & Not available \\
\hline JQ411588 & Italy & 1951 \\
\hline JQ411589 & Hungary & 2007 \\
\hline JQ411590 & Slovakia & 2007 \\
\hline JQ411591 & Lithuania & 2009 \\
\hline JX028200 & Guatemala & Not available \\
\hline JX028202 & Cuba & 2009 \\
\hline JX028204 & Cuba & 2010 \\
\hline JX028201 & Cuba & 1958 \\
\hline JX028203 & Cuba & 2011 \\
\hline AY526726 & Taiwan & 2003 \\
\hline AY526727 & Taiwan & 1994 \\
\hline AY526728 & Taiwan & 2001 \\
\hline AY526729 & Taiwan & 1995 \\
\hline AY526730 & Taiwan & 1996 \\
\hline AY526731 & Taiwan & 1990 \\
\hline AY526732 & Taiwan & \\
\hline U35069 & Taiwan & Not available \\
\hline U35740 & Taiwan & Not available \\
\hline X71780 & United Kingdom & Not available \\
\hline AJ704817 & Cuba & \\
\hline EU567076 & India & \\
\hline EU567077 & India & \\
\hline EU567078 & India & 2009 \\
\hline FJ160901 & India & \\
\hline KF007902 & India & 2009 \\
\hline KF007919 & India & \\
\hline HQ697222 & China & 2012 \\
\hline HQ697223 & China & 2008 \\
\hline HQ697224 & China & \\
\hline HQ697225 & China & 2008 \\
\hline HQ697226 & China & \\
\hline HQ697227 & & \\
\hline HQ697228 & & \\
\hline
\end{tabular}




\begin{tabular}{|l|l|l|}
\hline HCU03290 & Not available & Not available \\
\hline AH007708 & Not available & Not available \\
\hline DQ907712 & Not available & Not available \\
\hline DQ907713 & Not available & Not available \\
\hline DQ907714 & Not available & Not available \\
\hline DQ907715 & Not available & Not available \\
\hline DQ907716 & Not available & Not available \\
\hline DQ907719 & Not available & Not available \\
\hline NM_001204369 & Not available & Not available \\
\hline KX130940 & Indonesia & 2013 \\
\hline AF143082 & China & Not available \\
\hline AF143092 & China & Not available \\
\hline AF143083 & China & Not available \\
\hline AF143084 & China & Not available \\
\hline AF143085 & China & Not available \\
\hline AF143086 & China & Not available \\
\hline AF143087 & China & Not available \\
\hline AF143088 & China & Not available \\
\hline AF143089 & China & Not available \\
\hline AF143090 & China & Not available \\
\hline AF143091 & China & Not available \\
\hline KY990413 & Not available & Not available \\
\hline KY990414 & Bangladesh & 2015 \\
\hline KY990415 & Bangladesh & 2015 \\
\hline HCU72047 & Not available & Not available \\
\hline HCU72048 & Not available & Not available \\
\hline KC533781 & India & 2009 \\
\hline KC533787 & India & 2010 \\
\hline AY430287 & Not available & Not available \\
\hline DQ907717 & Not available & Not available \\
\hline DQ907718 & Not available & Not available \\
\hline DQ907720 & Not available & Not available \\
\hline KC533782 & India & Not available \\
\hline AY027672 & Not available & Not available \\
\hline AY027673 & Not available & Not available \\
\hline EF683605 & China & Not available \\
\hline EF683606 & China & Not available \\
\hline EF683607 & China & Not available \\
\hline EF683608 & China & Not available \\
\hline EF683609 available \\
\hline EF683610 & China & Not available \\
\hline EF683611 & China & \\
\hline EF683612 & \\
\hline EF683613 & \\
\hline
\end{tabular}




\begin{tabular}{|l|l|l|}
\hline EF683614 & China & Not available \\
\hline EF683615 & China & Not available \\
\hline EF683616 & China & Not available \\
\hline EF683617 & China & Not available \\
\hline EF683618 & China & Not available \\
\hline EF683619 & China & Not available \\
\hline EF683620 & China & Not available \\
\hline EF683621 & China & Not available \\
\hline EF683622 & China & Not available \\
\hline EF683623 & China & Not available \\
\hline FJ456865 & China & 2007 \\
\hline FJ456866 & China & 2007 \\
\hline FJ456867 & China & 2006 \\
\hline FJ456868 & China & 2007 \\
\hline FJ456869 & China & 2005 \\
\hline FJ456870 & China & 2004 \\
\hline FJ456871 & China & 2005 \\
\hline FJ456872 & China & 2006 \\
\hline FJ456873 & China & 2006 \\
\hline FJ456874 & China & 2006 \\
\hline FJ456875 & China & 2004 \\
\hline FJ456876 & China & 2007 \\
\hline FJ582642 & China & 2008 \\
\hline FJ582643 & China & 2008 \\
\hline FJ582644 & China & 2008 \\
\hline FJ598609 & China & 2008 \\
\hline FJ598610 & China & 2008 \\
\hline FJ598611 & China & 2008 \\
\hline FJ598612 & China & 2008 \\
\hline FJ607779 & China & 2008 \\
\hline FJ607780 & China & 2008 \\
\hline FJ977628 & China & 2009 \\
\hline HM190299 & South Africa & 2005 \\
\hline HQ317681 & China & 2010 \\
\hline HQ380232 & China & 2009 \\
\hline HQ380233 & China & 2010 \\
\hline HQ380234 & China & 2009 \\
\hline HQ380235 & China & 2008 \\
\hline HQ380236 & China & 2008 \\
\hline HQ380237 & China & 2008 \\
\hline HQ380238 & China & 2009 \\
\hline HQ380239 & & \\
\hline HQ380240 & China & \\
\hline
\end{tabular}




\begin{tabular}{|l|l|l|}
\hline HQ380242 & China & 2010 \\
\hline HQ38243 & China & 2010 \\
\hline HQ380244 & China & 2009 \\
\hline HQ38245 & China & 2009 \\
\hline JN882005 & China & 2011 \\
\hline JQ001833 & China & 2011 \\
\hline JQ001834 & China & 2011 \\
\hline JN886990 & China & 2011 \\
\hline JQ411592 & Lithuania & 2011 \\
\hline JQ411593 & Lithuania & 2011 \\
\hline JQ411594 & Lithuania & 2011 \\
\hline JQ411595 & Lithuania & 2011 \\
\hline JQ411596 & Lithuania & 2011 \\
\hline JQ411597 & Lithuania & 2011 \\
\hline JQ411598 & Lithuania & 2011 \\
\hline JQ411599 & Lithuania & 2011 \\
\hline JQ411600 & Lithuania & 2011 \\
\hline JQ411601 & Lithuania & 2011 \\
\hline JX162240 & Nepal & 2011 \\
\hline JX162241 & Nepal & 2011 \\
\hline JX898523 & China & 2011 \\
\hline JX898524 & China & 2012 \\
\hline JX898525 & China & 2012 \\
\hline KC597187 & China & 2012 \\
\hline KC809979 & China & 2011 \\
\hline KC809980 & China & 2012 \\
\hline KC809981 & China & 2011 \\
\hline KC809982 & China & 2011 \\
\hline KC809983 & China & 2011 \\
\hline KC809984 & China & 2011 \\
\hline KC809985 & China & 2011 \\
\hline KC809986 & China & 2012 \\
\hline KC867687 & China & 2011 \\
\hline KC867688 & China & 2012 \\
\hline KC867689 & China & 2012 \\
\hline KF297337 & Romania & 2007 \\
\hline KF233944 & Bulgaria & 1997 \\
\hline KF233945 & Croatia & 1997 \\
\hline KF233946 & Not available & 2000 \\
\hline KF233947 & Bulgaria & 2002 \\
\hline KF233948 & Romania & 2004 \\
\hline KF233949 & Bulgaria & 2006 \\
\hline KF233950 & 2006 \\
\hline KF233951 & 2007 \\
\hline
\end{tabular}




\begin{tabular}{|l|l|l|}
\hline KF233952 & Bulgaria & 2007 \\
\hline KF233953 & Croatia & 2007 \\
\hline KF233954 & Romania & 2006 \\
\hline KF233955 & Romania & 2006 \\
\hline KF233956 & Romania & 2007 \\
\hline KF233957 & Bulgaria & 2008 \\
\hline KF233958 & Israel & 2009 \\
\hline KF233959 & Bulgaria & 2009 \\
\hline KF233960 & Serbia & 2010 \\
\hline KF233961 & Latvia & 2013 \\
\hline KJ661548 & China & 2008 \\
\hline LC000001 & India & 2013 \\
\hline LC000002 & India & 2012 \\
\hline LC029886 & India & 2012 \\
\hline KP702206 & Viet Nam & 2014 \\
\hline KP702207 & Viet Nam & 2014 \\
\hline KP702208 & Viet Nam & 2014 \\
\hline KP702209 & Viet Nam & 2014 \\
\hline KP702210 & Viet Nam & 2014 \\
\hline KR054034 & India & Not available \\
\hline KR054035 & India & Not available \\
\hline KR054036 & India & Not available \\
\hline KR054037 & India & Not available \\
\hline KR054038 & India & Not available \\
\hline KR054039 & India & Not available \\
\hline KR054040 & India & Not available \\
\hline KR054041 & India & Not available \\
\hline KR054042 & India & Not available \\
\hline KR054043 & India & Not available \\
\hline KR054044 & India & Not available \\
\hline KR054045 & India & Not available \\
\hline KR054046 & India & Not available \\
\hline KR054047 & India & Not available \\
\hline KR054048 & India & Not available \\
\hline KR054049 & India & Not available \\
\hline KR054050 & India & Not available \\
\hline KR054051 & India & Not available \\
\hline KR054052 & India & Not available \\
\hline KT953587 & China & 2015 \\
\hline KT953588 & China & 2015 \\
\hline KT953589 & China & 2014 \\
\hline KT953590 & China \\
\hline KT953591 & China \\
\hline KT953592 & \\
\hline
\end{tabular}




\begin{tabular}{|l|l|l|}
\hline KT953593 & China & 2015 \\
\hline KT953594 & China & 2015 \\
\hline KT953595 & China & 2015 \\
\hline KT953596 & China & 2015 \\
\hline KT953597 & China & 2015 \\
\hline KT953598 & China & 2015 \\
\hline KT953599 & China & 2015 \\
\hline KT953600 & China & 2015 \\
\hline KT953601 & China & 2015 \\
\hline KT953602 & China & 2015 \\
\hline KT953603 & China & 2015 \\
\hline KT953604 & China & 2014 \\
\hline KT953605 & China & 2015 \\
\hline KT953606 & China & 2015 \\
\hline KT953607 & China & 2015 \\
\hline KT953608 & China & 2015 \\
\hline KT953609 & China & 2015 \\
\hline KT953610 & China & 2015 \\
\hline KT953611 & China & 2015 \\
\hline KT853102 & China & 2011 \\
\hline KT853103 & China & 2011 \\
\hline KT853104 & China & 2011 \\
\hline KT853105 & China & 2011 \\
\hline KT853106 & China & 2011 \\
\hline KT853107 & China & 2011 \\
\hline KT853108 & China & 2011 \\
\hline KT853109 & China & 2011 \\
\hline KT853110 & China & 2011 \\
\hline KT853111 & China & 2011 \\
\hline KT853112 & China & 2011 \\
\hline KT853113 & China & 2011 \\
\hline KT853114 & China & 2011 \\
\hline KT853115 & China & 2011 \\
\hline KT853116 & China & 2011 \\
\hline KU375249 & China & 2014 \\
\hline KU375250 & China & 2014 \\
\hline KU375251 & China & 2014 \\
\hline KU375252 & China & 2012 \\
\hline KU375253 & China & 2013 \\
\hline KU375254 & China & 2015 \\
\hline KU375255 & China & 2014 \\
\hline KU375256 & China & \\
\hline KU375257 & China & \\
\hline
\end{tabular}




\begin{tabular}{|l|l|l|}
\hline KU375259 & China & 2014 \\
\hline KU375260 & China & 2014 \\
\hline KU375261 & China & 2014 \\
\hline KU375262 & China & 2014 \\
\hline KU375263 & China & 2015 \\
\hline KX431227 & Brazil & 2008 \\
\hline KX431228 & Brazil & 2001 \\
\hline KX431229 & Brazil & 2003 \\
\hline KX431230 & Brazil & 2003 \\
\hline KX431231 & Brazil & 2004 \\
\hline KX431232 & Brazil & 2009 \\
\hline KX431233 & Brazil & 2009 \\
\hline KX687712 & Germany & 1989 \\
\hline KX687713 & Croatia & 2002 \\
\hline KX687714 & Croatia & 2002 \\
\hline KX687715 & Romania & 1994 \\
\hline KX687716 & Croatia & 2007 \\
\hline KX687717 & Bulgaria & 1998 \\
\hline KX687718 & Bulgaria & 2002 \\
\hline KX687719 & Slovakia & 2007 \\
\hline KX687720 & Germany & 1993 \\
\hline KX687721 & Hungary & 1992 \\
\hline KX759642 & China & 2009 \\
\hline KX759643 & China & 2006 \\
\hline KX257416 & China & Not available \\
\hline KX586754 & Ecuador & 2015 \\
\hline KX586755 & Ecuador & 2014 \\
\hline KX586756 & Ecuador & 2013 \\
\hline KX586757 & Ecuador & 2014 \\
\hline KX586758 & Ecuador & 2014 \\
\hline KX586759 & Ecuador & 2014 \\
\hline KX586760 & Ecuador & 2015 \\
\hline KX586761 & Ecuador & 2015 \\
\hline KX586762 & Ecuador & 2012 \\
\hline KX586763 & Ecuador & 2015 \\
\hline KX586764 & Ecuador & 2015 \\
\hline KX586765 & Ecuador & 2015 \\
\hline KX586766 & Ecuador & 2015 \\
\hline KX586767 & Ecuador & 2015 \\
\hline KX586768 & Ecuador & 2015 \\
\hline KX586769 & Ecuador & 2015 \\
\hline KX586770 & Ecuador & 2015 \\
\hline KX586771 & Ecuador & 2012 \\
\hline KX586772 & \\
\hline
\end{tabular}




\begin{tabular}{|l|l|l|}
\hline KX586773 & Ecuador & 2000 \\
\hline KX586774 & Ecuador & 2015 \\
\hline KY816735 & Not available & 2014 \\
\hline KY816736 & Not available & 2014 \\
\hline KY816737 & Not available & 2014 \\
\hline KY816738 & Not available & 2014 \\
\hline KY816739 & Not available & 2014 \\
\hline KX844724 & Not available & 2014 \\
\hline KX880080 & China & 2015 \\
\hline KX880081 & China & 2014 \\
\hline KX880082 & China & 2016 \\
\hline KX880083 & China & 2015 \\
\hline KX880084 & China & 2014 \\
\hline KX880085 & China & 2016 \\
\hline KX880086 & China & 2016 \\
\hline KX880087 & China & 2016 \\
\hline KX880088 & China & 2015 \\
\hline KX880089 & China & 2016 \\
\hline KX898427 & China & 2014 \\
\hline KX898428 & China & 2014 \\
\hline KX898429 & China & 2014 \\
\hline KX898430 & China & 2014 \\
\hline KX898431 & China & 2014 \\
\hline KX898432 & China & 2014 \\
\hline KX898433 & China & 2014 \\
\hline KX886270 & China & 2015 \\
\hline KX886271 & China & 2016 \\
\hline KX886272 & China & 2016 \\
\hline KX886273 & China & 2015 \\
\hline KX886274 & China & 2015 \\
\hline KX886275 & China & 2015 \\
\hline KX886276 & China & 2015 \\
\hline KX886277 & China & 2016 \\
\hline KX886278 & China & 2015 \\
\hline KX886279 & China & 2014 \\
\hline HCU43924 & Not available & Not available \\
\hline AF134207 & Thailand & Not available \\
\hline AF134208 & Thailand & Not available \\
\hline AF134209 & Thailand & Not available \\
\hline AF134210 & Thailand & Not available \\
\hline KC533777 & India & 2011 \\
\hline KC533779 & India & 2011 \\
\hline AY450271 & Not available & Not available \\
\hline AY450272 & Not available & Not available \\
\hline & \\
\hline
\end{tabular}




\begin{tabular}{|l|l|l|}
\hline AY450273 & Not available & Not available \\
\hline AY450274 & Not available & Not available \\
\hline AY450275 & Not available & Not available \\
\hline AY450276 & Not available & Not available \\
\hline AY450277 & Not available & Not available \\
\hline AY450278 & Not available & Not available \\
\hline AY450279 & Not available & Not available \\
\hline AY450280 & Not available & Not available \\
\hline AY450281 & Not available & Not available \\
\hline AY450282 & Not available & Not available \\
\hline AY450283 & Not available & Not available \\
\hline AY450284 & Not available & Not available \\
\hline EF014327 & Not available & Not available \\
\hline EF014328 & Not available & Not available \\
\hline EF014329 & Not available & Not available \\
\hline EF014330 & Not available & Not available \\
\hline EF014331 & Not available & Not available \\
\hline EF014332 & Not available & Not available \\
\hline EF014333 & Not available & Not available \\
\hline EF014334 & Not available & Not available \\
\hline EF014335 & Not available & Not available \\
\hline EF014336 & Not available & Not available \\
\hline EF014337 & Not available & Not available \\
\hline EF014338 & Not available & Not available \\
\hline KC533783 & India & 2006 \\
\hline AY430095 & Not available & Not available \\
\hline AY430096 & Not available & Not available \\
\hline KX345847 & Bangladesh & 2015 \\
\hline KP195022 & India & 2014 \\
\hline AF091507 & Not available & Not available \\
\hline AF091661 & Italy & 1951 \\
\hline AF092448 & China & Not available \\
\hline AF099102 & Russia & Not available \\
\hline AF326963 & Germany & 1965 \\
\hline AF333000 & China & Not available \\
\hline AF531433 & China & Not available \\
\hline AY259122 & Switzerland & Not available \\
\hline AY367767 & China & Not available \\
\hline AY382481 & Not availailable \\
\hline AY554397 & 2001 \\
\hline AY578687 & 2001 \\
\hline AY578688 & \\
\hline AY646427 & \\
\hline AY663656 & Taiwan \\
\hline
\end{tabular}




\begin{tabular}{|l|l|l|}
\hline AY775178 & China & 1945 \\
\hline AY805221 & China & Not available \\
\hline DQ127910 & China & 2004 \\
\hline EU490425 & France & Not available \\
\hline EU497410 & China & 2006 \\
\hline EU789580 & Japan & 1980 \\
\hline EU857642 & India & Not available \\
\hline FJ265020 & Spain & 2001 \\
\hline FJ529205 & China & 2010 \\
\hline GQ122383 & China & 2006 \\
\hline GQ902941 & Denmark & Not available \\
\hline GQ923951 & China & 2009 \\
\hline GU233731 & Germany & 2006 \\
\hline GU233732 & Germany & 2005 \\
\hline GU233733 & Germany & 2009 \\
\hline GU233734 & Germany & 2009 \\
\hline GU324242 & Germany & 2004 \\
\hline GU592790 & China & 2009 \\
\hline HM175885 & China & 2008 \\
\hline HM237795 & Czech Republic & Not available \\
\hline HQ148061 & Croatia & 2002 \\
\hline HQ148062 & Bulgaria & 2007 \\
\hline HQ148063 & Lithuania & 2009 \\
\hline HQ380231 & China & 2009 \\
\hline J04358 & Germany & 1999 \\
\hline JQ268754 & China & 2010 \\
\hline JQ861548 & India & 2011 \\
\hline JX218094 & China & 2012 \\
\hline JX262391 & China & 2011 \\
\hline KC149990 & South Korea & 2011 \\
\hline KC149991 & South Korea & 2011 \\
\hline KC503764 & India & 2011 \\
\hline KC533775 & India & 2006 \\
\hline KC533776 & India & Not available \\
\hline KC533793 & India & 2011 \\
\hline KC851953 & India & 2012 \\
\hline KF669877 & South Korea & 1998 \\
\hline KJ619377 & Netherlands & 1977 \\
\hline KJ873238 & USA & 1994 \\
\hline KM262189 & India & 2009 \\
\hline KM362426 & India & Not available \\
\hline KM522833 & USSR & 2013 \\
\hline KP233070 & \\
\hline KP233071 & \\
\hline
\end{tabular}




\begin{tabular}{|c|c|c|}
\hline KP343640 & China & 2011 \\
\hline KT119352 & China & 2014 \\
\hline KT716271 & South Korea & 1999 \\
\hline KU504339 & China & 2011 \\
\hline KU556758 & China & 2015 \\
\hline KX064281 & China & 2015 \\
\hline KX576461 & Cuba & 2010 \\
\hline KX870109 & South Korea & 2016 \\
\hline KY132096 & China & 2011 \\
\hline KY290453 & South Korea & 2016 \\
\hline KY860615 & India & 2013 \\
\hline LC086647 & Mongolia & 2014 \\
\hline LT158401 & Not available & Not available \\
\hline LT158402 & Not available & Not available \\
\hline LT158403 & Not available & Not available \\
\hline LT158404 & Not available & Not available \\
\hline LT158405 & Not available & Not available \\
\hline LT158406 & Not available & Not available \\
\hline LT158407 & Not available & Not available \\
\hline LT158408 & Not available & Not available \\
\hline LT158409 & Not available & Not available \\
\hline LT158410 & Not available & Not available \\
\hline LT158502 & Not available & Not available \\
\hline M31768 & Netherlands & Not available \\
\hline NC_00265 & Switzerland & 2000 \\
\hline U35069 & Taiwan & Not available \\
\hline $\mathrm{U} 35740$ & Taiwan & Not available \\
\hline U43924 & Taiwan & Not available \\
\hline $\mathrm{U} 45477$ & Germany & Not available \\
\hline U72047 & China & Not available \\
\hline U72048 & Not available & Not available \\
\hline U90951 & France & Not available \\
\hline X87939 & Switzerland & Not available \\
\hline X96550 & Switzerland & Not available \\
\hline LT593749 & Duplicated & \\
\hline LT593750 & Duplicated & \\
\hline LT593751 & Duplicated & \\
\hline LT593757 & Duplicated & \\
\hline LT593758 & Duplicated & \\
\hline LT593748 & Duplicated & \\
\hline LT593754 & Duplicated & \\
\hline LT593760 & Duplicated & \\
\hline LT593753 & Duplicated & \\
\hline LT593755 & Duplicated & \\
\hline
\end{tabular}




\begin{tabular}{|l|l|l|}
\hline LT593756 & Duplicated & \\
\hline LT593761 & Duplicated & \\
\hline LT593762 & Duplicated & \\
\hline KF007902 & Duplicated & \\
\hline KF007919 & Duplicated & \\
\hline HQ697227 & Duplicated & \\
\hline HQ697228 & Duplicated & \\
\hline KY990413 & Duplicated & \\
\hline KY990414 & Duplicated & \\
\hline KY990415 & Duplicated & \\
\hline KC533781 & Duplicated & \\
\hline KC533787 & Duplicated & \\
\hline HQ380235 & Duplicated & \\
\hline HQ380244 & Duplicated & \\
\hline HQ380245 & Duplicated & \\
\hline JQ411593 & Duplicated & \\
\hline JQ411594 & Duplicated & \\
\hline JQ411595 & Duplicated & \\
\hline JQ411596 & Duplicated & \\
\hline JQ411597 & Duplicated & \\
\hline JQ411598 & Duplicated & \\
\hline JQ411599 & Duplicated & \\
\hline JQ411600 & Duplicated & \\
\hline JQ411601 & Duplicated & \\
\hline KT853104 & Duplicated & \\
\hline KT853108 & Duplicated & \\
\hline KT853109 & Duplicated & \\
\hline KT853110 & Duplicated & \\
\hline KT853112 & Duplicated & \\
\hline KT853114 & Duplicated & \\
\hline KT853113 & Duplicated & \\
\hline KT853115 & Duplicated & \\
\hline KU375249 & Duplicated & \\
\hline KU375250 & Duplicated & \\
\hline KX586760 & Duplicated & \\
\hline KX586765 & Duplicated & \\
\hline KX586768 & Duplicated & \\
\hline KX586769 & Duplicated & \\
\hline & & \\
\hline
\end{tabular}


Table S2. Genetic distances based on full-length E2 gene sequences of all the lineages assessed within the CSFV genotype 1. Values above the diagonal represent the standard error, values below the diagonal represent the p-distance values obtained using MEGA7 and 1000 bootstrap replicates.

\begin{tabular}{|r|ccccccccccc|}
\hline Subgenotype & $\mathbf{1 . 1}$ & $\mathbf{1 . 2}$ & $\mathbf{1 . 3}$ & $\mathbf{1 . 4}$ & $\mathbf{1 . 5}$ & $\mathbf{1 . 6}$ & $\mathbf{1 . 7}$ & $\mathbf{1 . 8}$ & $\mathbf{1 . 9}$ & $\mathbf{1 . 1 0}$ & $\mathbf{1 . 1 1}$ \\
\hline $\mathbf{1 . 1}$ & & 0.007 & 0.008 & 0.009 & 0.002 & 0.001 & 0.002 & 0.005 & 0.005 & 0.006 & 0.004 \\
$\mathbf{1 . 2}$ & 0.096 & & 0.006 & 0.004 & 0.008 & 0.009 & 0.005 & 0.007 & 0.007 & 0.008 & 0.007 \\
$\mathbf{1 . 3}$ & 0.104 & 0.102 & & 0.009 & 0.001 & 0.010 & 0.009 & 0.008 & 0.008 & 0.009 & 0.008 \\
$\mathbf{1 . 4}$ & 0.116 & 0.107 & 0.120 & & 0.011 & 0.010 & 0.010 & 0.010 & 0.009 & 0.010 & 0.010 \\
$\mathbf{1 . 5}$ & 0.096 & 0.131 & 0.138 & 0.134 & & 0.007 & 0.009 & 0.008 & 0.008 & 0.008 & 0.008 \\
$\mathbf{1 . 6}$ & 0.095 & 0.118 & 0.137 & 0.134 & 0.098 & & 0.009 & 0.008 & 0.008 & 0.009 & 0.008 \\
$\mathbf{1 . 7}$ & 0.096 & 0.104 & 0.128 & 0.131 & 0.108 & 0.106 & & 0.008 & 0.008 & 0.009 & 0.009 \\
$\mathbf{1 . 8}$ & 0.041 & 0.083 & 0.099 & 0.113 & 0.089 & 0.081 & 0.085 & & 0.005 & 0.006 & 0.005 \\
$\mathbf{1 . 9}$ & 0.049 & 0.083 & 0.102 & 0.111 & 0.100 & 0.090 & 0.091 & 0.044 & & 0.006 & 0.005 \\
$\mathbf{1 . 1 0}$ & 0.055 & 0.100 & 0.113 & 0.123 & 0.106 & 0.101 & 0.100 & 0.061 & 0.069 & & 0.006 \\
$\mathbf{1 . 1 1}$ & 0.032 & 0.078 & 0.098 & 0.104 & 0.087 & 0.081 & 0.088 & 0.039 & 0.046 & 0.054 & \\
\hline
\end{tabular}


Table S3. Genetic distances based on full-length E2 gene sequences of all the lineages assessed within the CSFV genotype 2. Values above the diagonal represent the standard error, values below the diagonal represent the p-distance values obtained using MEGA7 and 1000 bootstrap replicates.

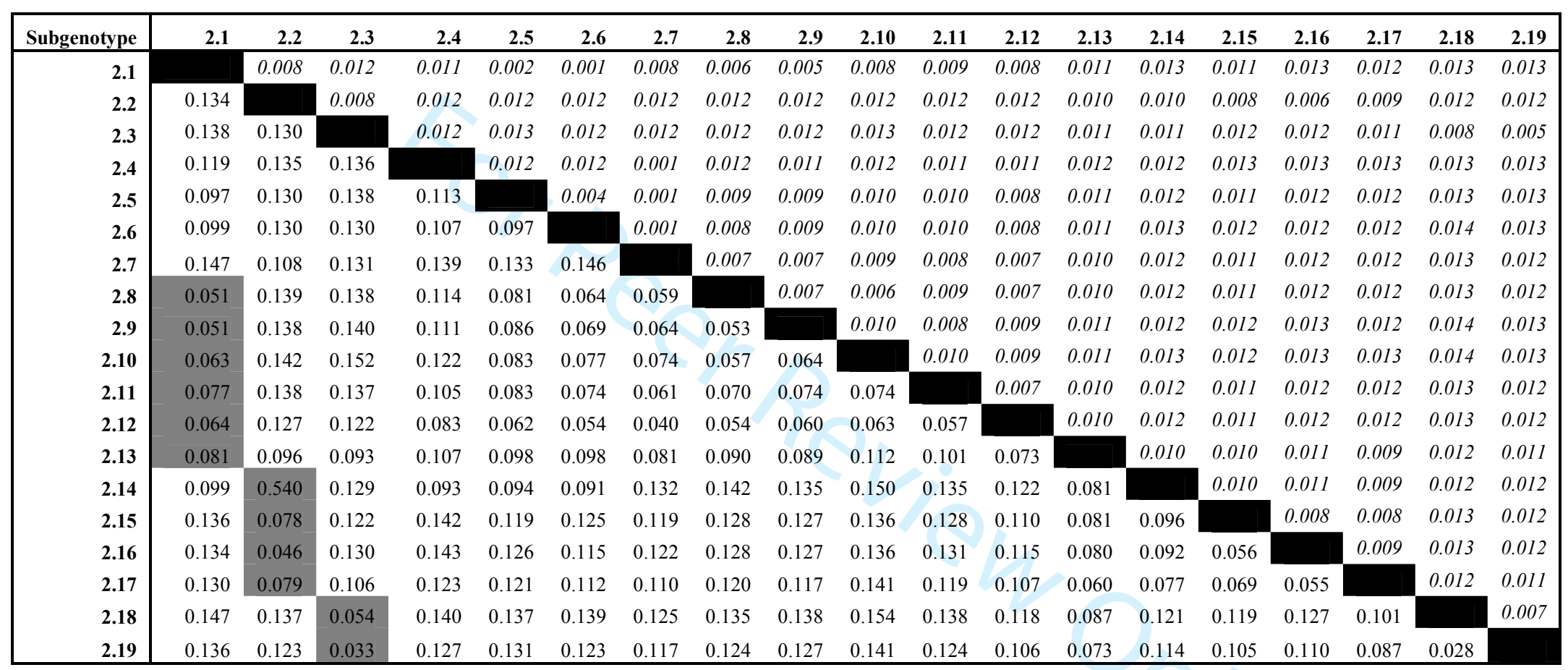


Table S4. Genetic distances based on full-length E2 gene sequences of all the lineages assessed within the CSFV genotype 3. Values above the diagonal represent the standard error, values below the diagonal represent the p-distance values obtained using MEGA7 and 1000 bootstrap replicates.

\begin{tabular}{|r|ccc|}
\hline Subgenotype & $\mathbf{3 . 1}$ & $\mathbf{3 . 2}$ & $\mathbf{3 . 3}$ \\
\hline $\mathbf{3 . 1}$ & & 0.007 & 0.006 \\
$\mathbf{3 . 2}$ & 0.047 & & 0.004 \\
$\mathbf{3 . 3}$ & 0.044 & 0.022 & \\
\hline
\end{tabular}


Table S5. Genetic distances based on full-length E2 gene sequences of all the lineages assessed within the CSFV genotype 5. Values above the diagonal represent the standard error, values below the diagonal represent the p-distance values obtained using MEGA7 and 1000 bootstrap replicates.

\begin{tabular}{|r|c|c|}
\hline Subgenotype & $\mathbf{5 . 1}$ & $\mathbf{5 . 2}$ \\
\hline $\mathbf{5 . 1}$ & & 0.006 \\
$\mathbf{5 . 2}$ & 0.045 & \\
\hline
\end{tabular}




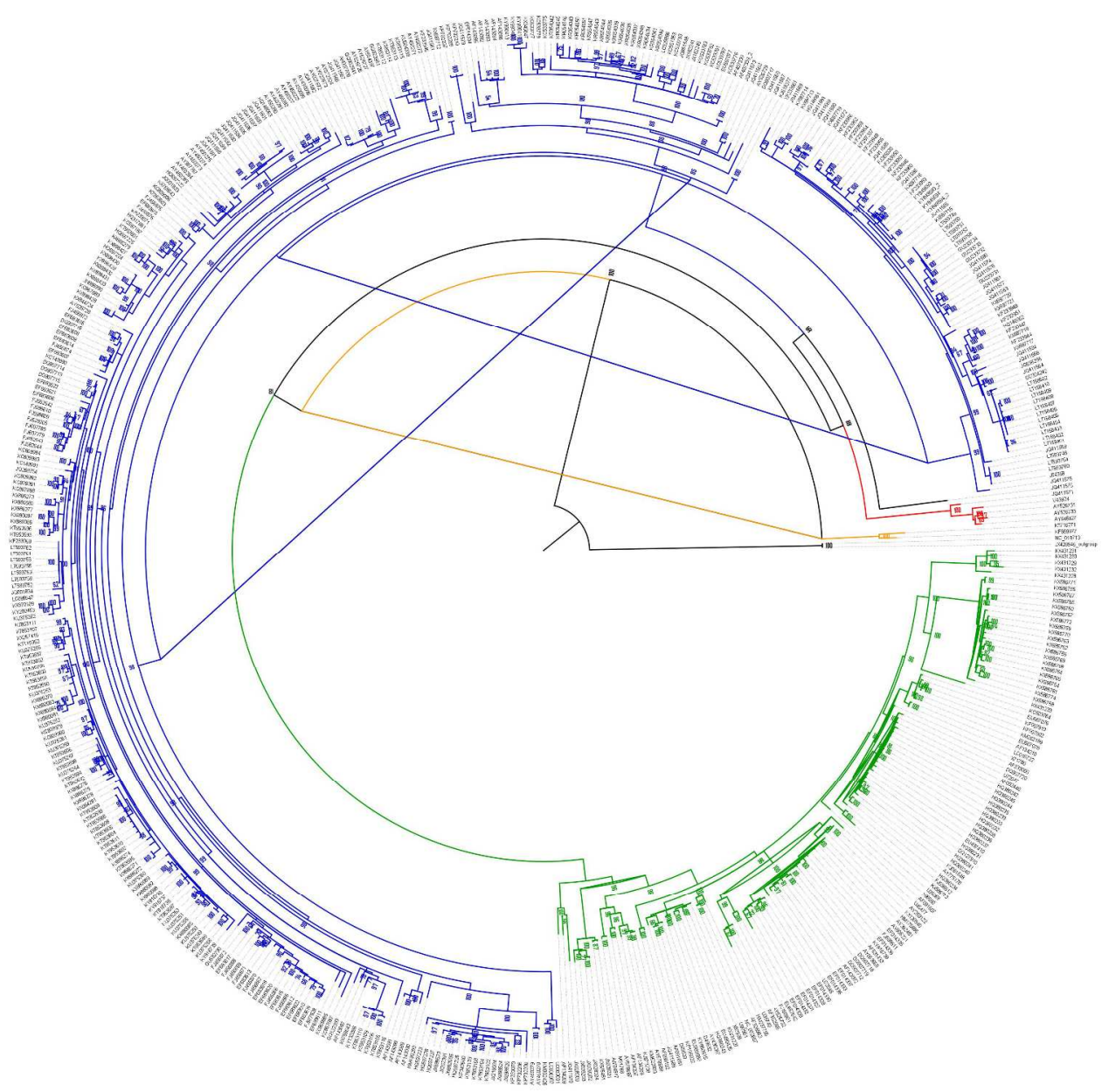

Figure S1

$257 \times 257 \mathrm{~mm}(300 \times 300 \mathrm{DPI})$

Transboundary and Emerging Diseases - submitted manuscript 


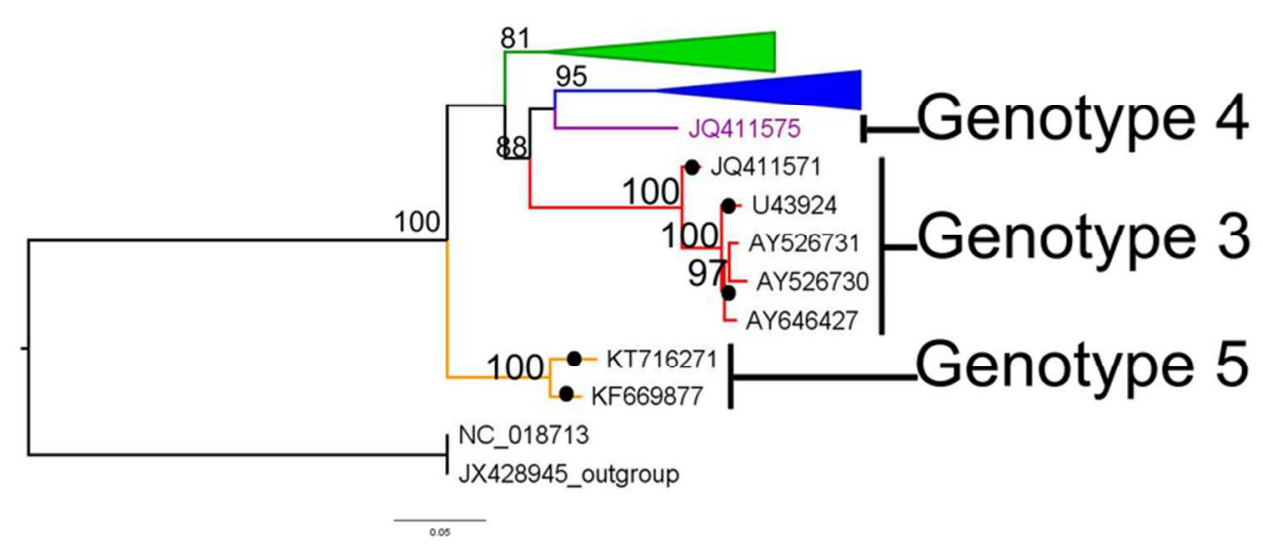

Figure S2

$76 \times 45 \mathrm{~mm}(300 \times 300 \mathrm{DPI})$ 